\title{
INGEKOMEN BOEKWERKEN
}

De Accountant, Verslag studievergadering 12 Juli 1941 (inleiding $D r B$. Schendstok), Het Besluit op de Inkomstenbelasting 1941). Uitgave van het Nederlandsch Instituut van Accountants, September 1941.

Dr O. Bakker, Statistiek. Deel I, De statistische methode, derde druk. Uitgave van J. Muusses, Purmerend, 1941. Prijs ingenaaid $f 4.50$, gebonden $f 5.25$.

Drs J. Slikboer, Practische psychologie. Deel III van de reeks Bedrijfseconomische monografieën. Uitgave van H. E. Stenfert Kroese's Uitg. Mij. N.V., Leiden, 1941. Prijs ingenaaid f 8.-, gebonden $f 9.50$.

A. L. F. Leverington. Hoe moet het aangiftebiljet A voor de Inkomstenbelasting 1941 worden ingevuld? Uitgave van L. J. Veen's Uitgevers Mij. N.V., Amsterdam, 1941. Prijs ingenaaid $f$ 1.25.

P. Karmelk, Wet op de Inkomstenbelasting 1914, supplement 8; Loonbelasting supplement 4. Uitgave van J. Noorduyn en Zoon N.V., Gorinchem, 17 September 194,1, in de serie De Belastingwetgeving. Prijs $f 0.65$.

Dr J. C. Choufoer, E. Smit en W. Speerstra, Leerboek van het boekhouden. Deel I, ten dienste van het onderwijs in de derde klasse H.B.S. (A. en B.); 2 druk. Uitgave van J. B. Wolters' Uitgevers-Mij. N.V., Groningen, 1941. Prijs ingenaaid $f 2.60$, gebonden $f 2.90$.

A. W. Berger, B. de Boer en H.W. Pietersma, Eenvoudig Boekhouden voor U.L.O.; deel I, 2e druk. Uitgave van J. B. Wolters' UitgeversMij. N.V., Groningen, 1941. Prijs ingenaaid f 1.35, gebonden $f 1.55$.

van Steenbergen, De Zegelwet 1917; bewerkt door $H$. Schuttevaêr, 6e druk. Uitgave van N. Samson, N.V., Alphen aan den Rijn, 1941. Prijs f 6.75 .

Dr M. J. H. Smeets en J. H. Meihuizen, Supplement no. 4 op de Beknopte Belastinggids. Uitgave van L. J. Veen's Uitgevers Mij. N.V., Amsterdam, 1941. Prijs $f$ 1., .

Joh. Hage, Koersberekening. Uitgave van P. Noordhoff N.V., Groningen, 1941; 2 e druk. Prijs ingenaaid f 3.90; gebonden $f 4.60$.

A. A. D. Bouwhof en J. C. Lagerwerff. Supplement A op Handelsrekenen, 3e druk. Uitgave van P. Noordholf N.V., Groningen, 1941. Prijs ingenaaid $f 6.75$, gebonden $f 7.25$. 